\title{
Importance Performance Analysis (IPA) Visitors' Satisfaction of Ecotourism in Bangka Belitung, Indonesia: Tracking the Messages to Stakeholders
}

\author{
Ibrahim Ibrahim $^{1 *}$, Nizwan Zukhri ${ }^{2}$, and Rendy Rendy ${ }^{1}$ \\ ${ }^{1}$ Department of Political Science, Universitas Bangka Belitung, Gg. IV No.1, Balun Ijuk, \\ Balunijuk 33172, Bangka, Indonesia. \\ ${ }^{2}$ Department of Management, Universitas Bangka Belitung, Gg. IV No.1, Balun Ijuk, \\ Balunijuk 33172, Bangka, Indonesia.
}

\begin{abstract}
The satisfaction of visitors is an important part of developing tourism. Knowing satisfactory of the visitor and the dimension will be advantage and weakness of a tourism visit, stakeholders are able to figure out what must be done. This study used the Importance Performance Analysis (IPA) method to find out the satisfactory of visitors. There are some interesting findings in this study, such as the fact that Bangka Belitung visitors' satisfactory is quite high, but the disparity of visitors' satisfaction is quite high and put Belitung on the good quadrant. However, Bangka needs more concern. This study also found that supporting facilities and transportation still become a serious problem. On the other side, the value of eco-tourism has not met the standard, such as education, environment protection, and voluntarism value. The local Stakeholders need to put extra concern on supporting facilities and maintain that has been considered as good, such as the natural beauty and the locals' hospitality.
\end{abstract}

Keywords: Advantage and weakness of a tourism visit, developing tourism, increase income, Laskar Pelangi.

\section{Introduction}

Although known as a beautiful archipelago with many islands and beaches, the position of the Bangka Belitung Islands Province is not yet one of the main tourist destinations in Indonesia. The archipelago, which is located on the east side of the island of Sumatra, is more widely known as an area of tin mining and producing white pepper for a long time [1-4]. However, this condition slowly changed with the popularity of Andrea Hirata's novel entitled Laskar Pelangi and was soon followed by the film Laskar Pelangi [5].

Although the Laskar Pelangi film only popularized the island of Belitung and has a cultural angle in it, as a result, in recent years' tourist visits have increased sharply on these two islands [6-9]. The fact is that these two islands have a long white coastline, some of which are formed in small islands. Local governments on these two islands have also

*Corresponding author: $\underline{\text { iim_babel@yahoo.com }}$ 
established the tourism sector as an alternative economic sector for the region in the future [10].

However, there is an interesting question, how is the real tourism development in this area? This can be measured from the satisfaction of the visitors on these two islands. The satisfactory has various dimensions because the tourism sector doesn't stand alone [11-14]. Basically, the tourism sector involves many stakeholders. Beside the stakeholders, there are others that become part of the tourism destination [15]. The government also plays an important role, considering the policy, planning, preparation of supporting sector, to the building of tourism-aware community $[16,17]$.

As the area that relies on eco-tourism, it is important to pay attention to the supporting resources $[18,19]$. This study is designed to understand how is the satisfaction of visitors toward tourism in Bangka Belitung. The development of tourism, which is quite drastic in recent years, which is marked by improving hotel facilities, airlines, and tourist events, needs to be developed seriously and tracking how visitor satisfaction will be important means to know the weaknesses and strengths of the Bangka Belitung tourism sector.

\section{Research Method}

This writing is obtained from the survey towards 65 respondents selected and spread in all districts and cities in the Bangka Belitung Islands Province. The respondents were visitors from outside Bangka Belitung, who stayed at one of the hotel facilities in this area. Visitors answer questions that are arranged in private after they have completed their tour. The data analysis technique used is Importance Performance Analysis (IPA) by comparing expectations and reality. There are 22 statements submitted using the Likert scale. The quadrant analysis is then performed with the formula:

$$
\overline{X i}=\frac{\sum_{i=1}^{k} X i}{n} \quad \bar{Y} i=\frac{\sum_{i=1}^{k} Y i}{n}
$$

whereas:

$\overline{X i}=$ Weight of the average level of performance rating of the $\mathrm{i}$ attribute

$\bar{Y} i=$ Weight of the average level of importance assessment of the i attribute

$\mathrm{n}=$ Number of respondent

The next step is calculating the average level of importance and work towards the whole attributs with the formula:

$$
\overline{X i}=\frac{\sum_{i=1}^{k} \overline{X i}}{n} \quad \overline{Y i}=\frac{\sum_{i=1}^{k} \overline{Y i}}{n}
$$

whereas:

$\overline{\overline{X i}}=$ The average weight of the work scoring level of atribute $-\mathrm{i}$

$\overline{\bar{Y}} i=$ The average weight of the tendency scoring level of atribute $-\mathrm{i}$

$\mathrm{n}=$ Number of atribute

Value $\overline{\bar{X}}$ crosses the horisontal axis perpendicularly. It is the axis that shows the work of atribute $(\mathrm{X})$, whereas the value of $\overline{\bar{Y}}$ crosses the vertical axis perpendicularly, it is the axis that shows the need of (Y) atribute. The result is put into the Cartesien diagram, as shown in Figure 1. 


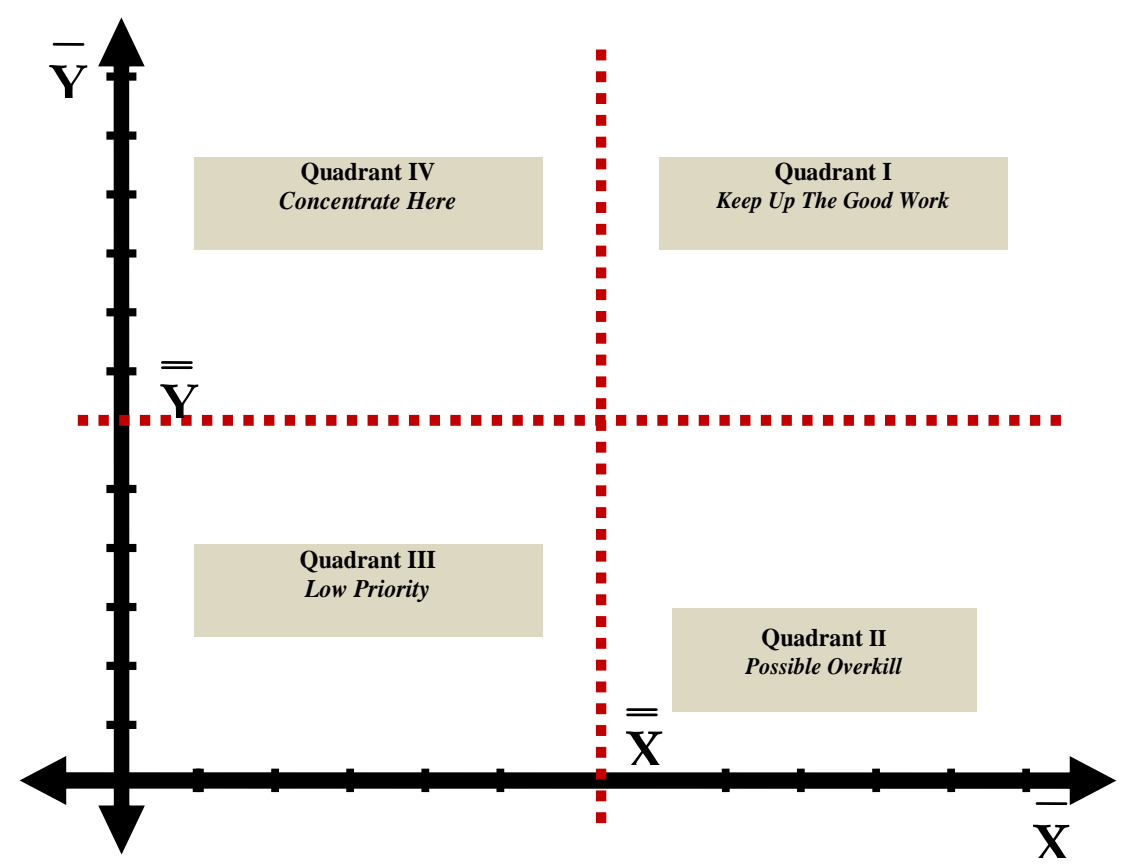

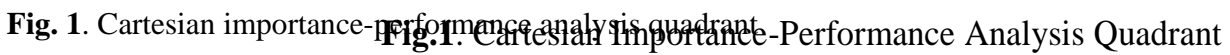

i. Quadrant 1: Keep Up The Good Work, shows that atributes is necesarry to the tourist as the basis of the decision of performance and good quality of service.

ii. Quadrant 2: Possible Overskill, showing fewer attributes, but having good quality.

iii. Quadrant 3: Low Priority, showing that some attributes are decreasing, lower than the average score.

iv. Quadrant 4: Concentrate Here (High Priority), showing attributes that are important in decision making, but do not have good quality.

\section{Finding and discussion}

Bangka Belitung is two big islands that have $1.4 \times 10^{6}$ citizens with approximate $70 \%$ of people live on Bangka island, and the rest is on Belitung Island. Both islands are connected with the airport, which takes 45 min of travelling time and $4 \mathrm{~h}$ if using a boat. Although both of them are different, mostly people think that Bangka and Belitung as one geographical unit and located on the same island. The characteristics of both islands are basically the same. Geographically, these islands are surrounded by many small islands that offer beauties; some of them are occupied. Demographically, the people on this island are the same. They are dominated by Malay ethnic. The second majority is Chinese ethnic [20-22]. The religion of the majority of people is Moslem, and many other ethnics that make the area is various in identity, but they are open minded and pluralistic.

Although these areas are identical in many things, they are different in tourism development, and these two are quite different. While these two areas have the beautiful coastal line and similar potential resources, Belitung island was known earlier, especially 
since the last decade for the popularity of the movie Laskar Pelangi. The Province government basically expecting the same development to these islands, however during the process, it needs a study on the visitors' satisfactory towards the natural resources in these areas, which will be the contribution of the province.

\subsection{IPA analysis on the visitors' satisfaction of Bangka}

The following is a quadrant figure of visitor satisfaction with tourism on Bangka Island.

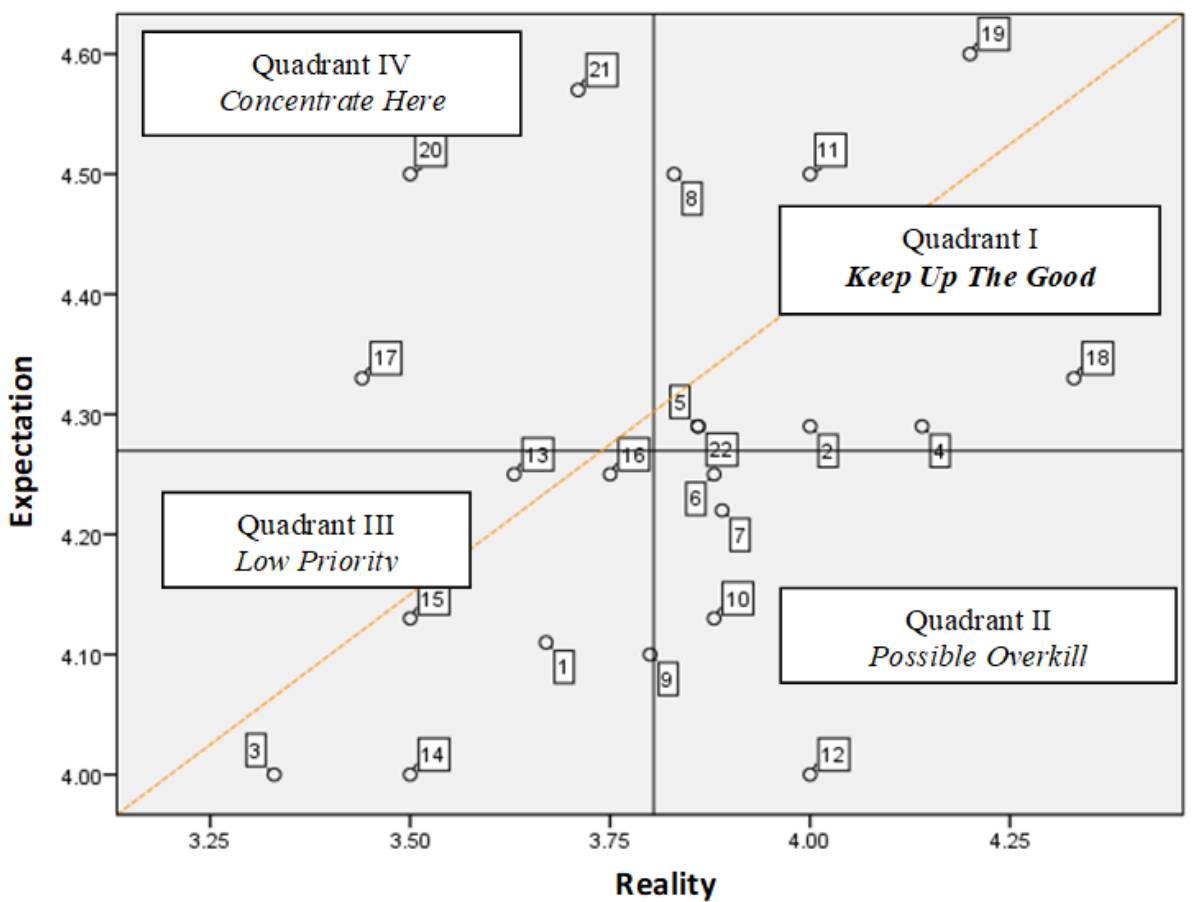

Fig. 2. Quadrant of visitors satisfaction of Bangka

Based on the quadrant of Figure 2 there are eight parts that is important and has good score and must be maintained as the achievement, they are people's hospitality, tasty food, natural beauty, comfort at the tourist destination location, suitability of the intended destination, hotel comfort, the beauty of the city atmosphere, and the readiness of Bangka as a tourist destination. Meanwhile, things that are considered less important for tourists, but are available with good value are the diversity of alternative options, ease of travel routes, the adequacy of facilities at the destination, the hospitality of the destination manager, and the suitability of promotions with the destination.

Menwhile, there are at least six parts that are expected to have a low score, they are the comfort of the airport, transportation facilities, development potential on the destination, education value on the destination, natural protection on the destination, and voluntarism on the destination. Whereas the quadrant IV is the category that needs special concern and what must be concentrated on this quadrant is the availability of souvenir shop, the support of Regional Government in the development, and visitors' satisfaction. 


\subsection{The IPA analysis of the visitors' satisfaction in Belitung}

Below is the quadrant table of the visitors satisfaction towards tourism in Belitung Island:

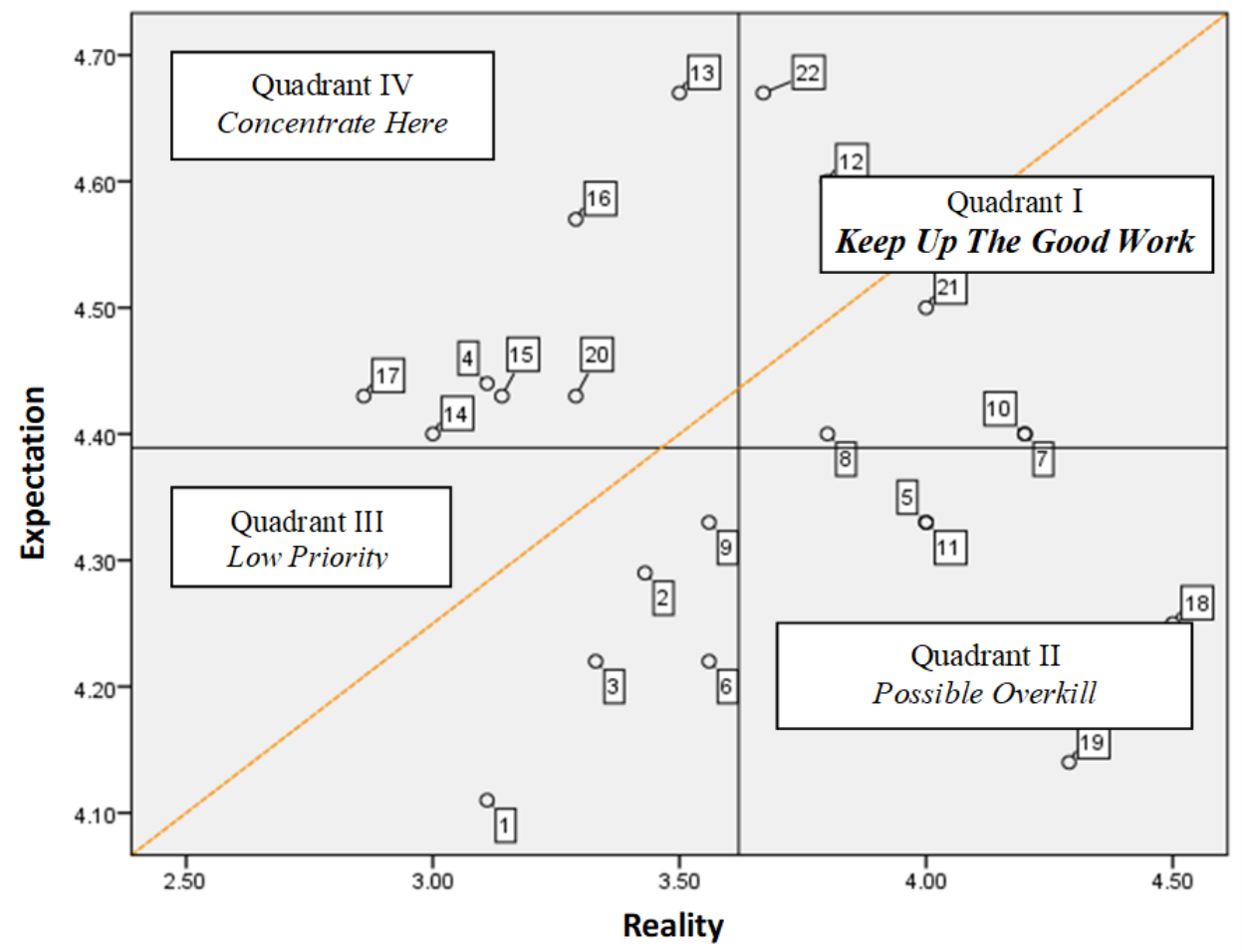

Fig. 3. Visitors' satisfaction quadrant of Belitung

Based on the quadrant in Figure 3. the satisfaction of visitors in Belitung, it is shown that on quadrant I, good categories that must be maintained are the hospitality of destination manager, the coherence of promotion and destination, visitors' satisfaction, natural beauty, ease of access, and the readiness of Belitung as a favorite tourism destination. Whereas on the Quadrant II that belongs to the less important category, but has good service are the coherence of destination with the previous plan, the comfort in the destination, locals' hospitality, and tasty local culinary.

In the quadrant III, those who belong to low score categories were the comfort in the airport, hotel facilities, transportation facilities, the various alternative of destination, and sufficient facilities on the destination. Then on the Quadrant IV, there were some parts need more concern and must put more effort on those, they are the city situation, development of destination potential, voluntarism in the destination, support of the government in developing and the availability of souvenir shops.

\subsection{IPA analysis of visitors in Bangka Belitung}

Accumulatively, the visitor satisfaction quadrant table for all respondents on both islands is illustrated as follows: 


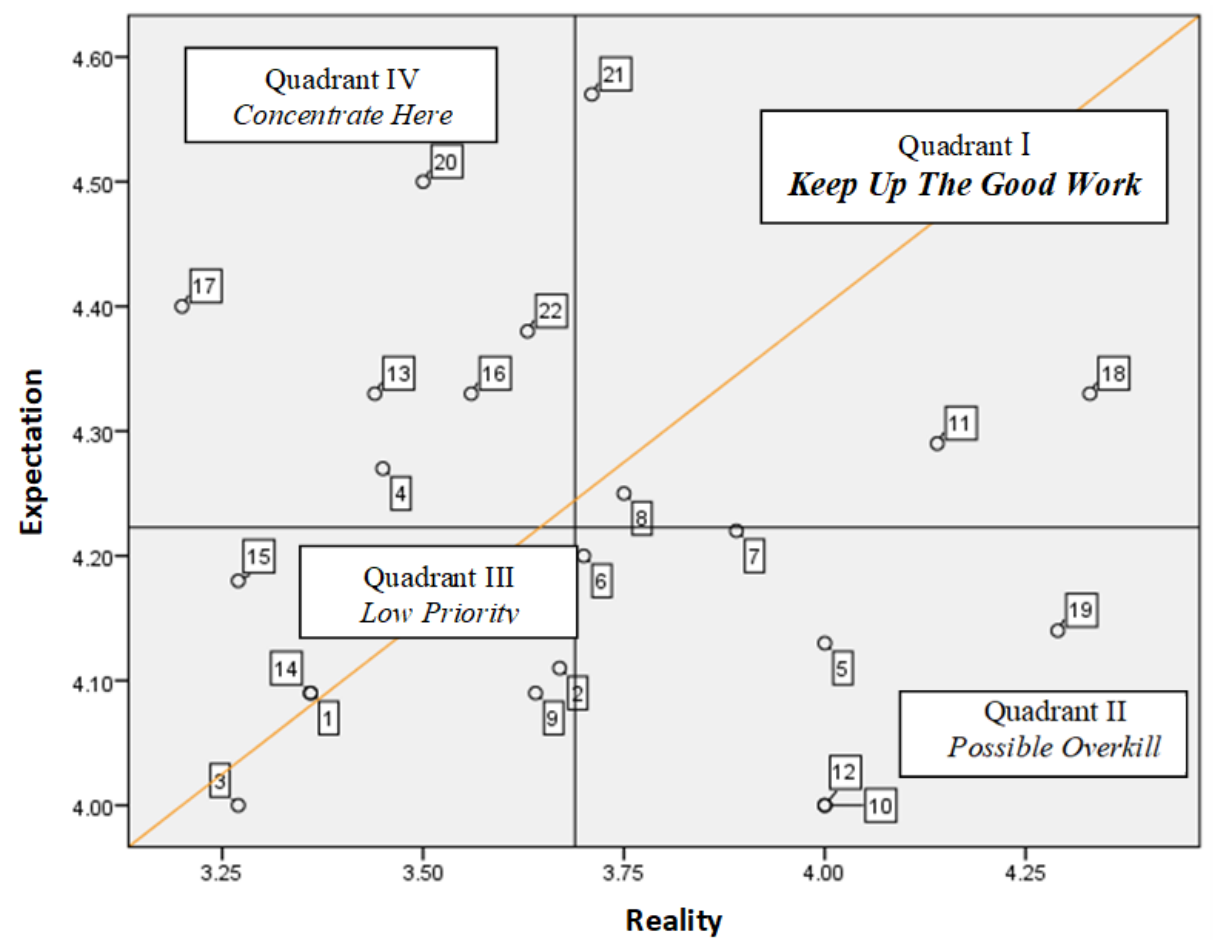

Fig. 4. Satisfactory Quadrant of the visitors in Bangka Belitung

Looking at the data of these two islands, accumulatively on the quadrant I, which belong to the category of must be maintained for having a good score on the visitors' satisfaction, people's hospitality, comfort in the destination, and natural beauty of the destination. Those who belong to Quadrant II were included in the good category but less significant according to the visitors were the compatibility of destination with the plan, alternative variety of the destination, ease of access, the hospitality of the administrator, the coherence of promotion, and the tasty local culinary.

Meanwhile, those who belong to the category of low priority or low score were convenience at the airport, hotel comfort, comfort of transportation facility, adequacy of facilities at the destination, educational value at the destination, and environmental protection at the destination. As for what is included in the category requiring special attention to quadrant IV is the beauty of the city situation, the potential for destination development, the value of voluntarism in the destination, local government support in development, and the availability of souvenir/souvenir centers, and the readiness of Bangka Belitung as a favorite destination.

\subsection{Notes for stakeholders}

Based on the survey findings in this study, it is interesting to examine several things. First, that in general visitors in this area are satisfied with their visit. However, there is a very sharp gap between visitors in Bangka and Belitung. Visitors in Bangka actually place visitor satisfaction in quadrant IV or in the category must be considered, while in visitor satisfaction in Belitung, visitors place it in quadrant I. That is, local governments need to pay special attention to visitor satisfaction on Bangka Island. The data as shown in Figure 
2, it appears that things that must be considered are aspects of the availability of souvenirs/souvenirs and the support of Local Government in the development of tourism.

Second, it is interesting to see that the people's hospitality, natural beauty, and convenience in the tourism destination get a good score from the visitors. All stakeholders need to keep the good aspects that are valued well by the visitors. However, the stakeholders need to put effort into making strategies for keeping some concerned

Second, it is interesting to note that the hospitality of its inhabitants, its natural beauty, and the convenience of being in a tourist destination get good value from visitors. Stakeholders need to maintain aspects that are considered good by visitors. However, stakeholders need to pay attention to strategies to maintain some of the aforementioned matters because they are basically natural and difficult to be intervened by local governments and other stakeholders. This means that the success that put visitor satisfaction in quadrant $\mathrm{I}$ is not part of local government intervention.

Third, it is interesting to put more effort into some that considered weak, whether in Bangka or Belitung, is the supporting facilities, they are the facilities of airport, hotel, transportation, and facilities in the tourism destination [23]. This is in line with the government's commitment to developing the tourism sector [24, 25]. In many parts, many quarrelled about facilities and transportation. In the middle of tourist development, it is important for the local stakeholder to prepare the support facilities and infrastructure at the local level, as mentioned by Lestari [26] that tourism is related to the facilities and services $[27,28]$.

Fourth, the visitors considered that aspects of eco-tourism had not been maximized in developing tourist destinations, namely concerning the value of education, the value of protection, and aspects of voluntarism in the development of tourism in this area. Local government support, the availability of souvenir facilities / souvenirs, eventually becomes a weak value that causes visitors to place Bangka Belitung readiness as a favorite tourist destination still in quadrant IV, which needs special attention.

\section{Conclusion}

This study concludes that in general, Bangka Belitung tourist visitors expressed satisfaction with their visit to Bangka Belitung, although it should be noted that visitor satisfaction in Bangka and Belitung is in a distant disparity. Belitung visitors express their satisfaction on the highest quadrant, while the opposite is Bangka's visitor on the lowest quadrant. This study also found that several things that must be considered by local governments include airport support facilities, transportation, and the availability of souvenirs / souvenirs. On the other hand, it was found that the visitors actually still did not see the value of ecotourism in the development of tourist destinations in this area, both in terms of educational value, environmental protection, and voluntary values. In the end, stakeholders should focus on developing destinations that are likely to be intervened, while those concerning satisfaction on the basis of existing conditions need to be maintained.

\section{Acknowledgments}

Thanks to Directorate of Higher Education of Ministry of Research, Technology, and Higher Education for supporting this research by National Competitive Research Grant 2019-2021. [Number 164/SP2H/LT/DRPM/2019]. 


\section{References}

1. M.F.S. Heidhues, Timah Bangka dan Lada Mentok, Peran Masyarakat Tionghoa dalam Pembangunan Pulau Bangka Abad XVIII s/d Abad XX. [Bangka Tin and Mentok Pepper: Chinese Settlement on an Indonesian Island], Jakarta: Yayasan Nabil (2008), p. 2-15. [in Bahasa Indonesia]. https://www.worldcat.org/title/timah-bangkadan-lada-mentok-peran-masyarakat-tionghoa-dalam-pembangunan-pulau-bangkaabad-xviii-sd-abad-xx/oclc/697276903

2. A. Reid, Chinese on The Mining Frontier in Southeast Asia in Chinese Circulations, Capital, Commodities, and Networks in Southeast Asia. E. Tagliacozzo, W-C. Chang (Eds). Durham and London: Duke University Press. (2011). p. 21-36. http://www.oapen.org/download?type=document\&docid=1004298

3. U. Bahari. Bangka Tin Magnets from Time to Time on Kelekak Sejarah Bangka, Department of culture and tourism of Bangka Regency. Sungailiat: Dinas Kebudayaan dan Pariwisata Kabupaten Bangka (2015). p. 218. [in Bahasa Indonesia]. [Online unpublished].

4. Ibrahim, Dwi Haryadi, \& Nanang Wahyudin, Masyarakat, Kebudayaan dan Politik, 31,4:358-367(2018). [in Bahasa Indonesia]. https://ejournal.unair.ac.id/MKP/article/view/7376

5. A. Sofia, Jurnal Ilmiah Sosiologi Agama, 9,1:1-21(2015). [in Bahasa Indonesia]. http://ejournal.uin-suka.ac.id/ushuluddin/SosiologiAgama/article/view/1132

6. D. Valeriani, Journal Equity, 1,4:1-27(2010). http://portalgaruda.org/?ref=browse \&mod=viewarticle\&article $=151923$

7. R.S. Wardhani, D. Valeriani, Global Economic Scientific Journal, 7,1:24-29(2016). http://jurnal.bakrie.ac.id/index.php/INDOCOMPAC/article/view/1608

8. BPS. Tingkat Penghunian Kamar Hotel Provinsi Kepulauan Bangka Belitung 2018. Pangkal Pinang: BPS-Statistics of Kepulauan Bangka Belitung Province (2019). p. 13-18. [in Bahasa Indonesia]. https://babel.bps.go.id/publication/2019/07/17/63dd70a6955254585d722c2f/tingkatpenghunian-kamar-hotel-provinsi-kepulauan-bangka-belitung-2018.html

9. BPS. Kepulauan Bangka Belitung Province in Figures. Provinsi Kepulauan Bangka Belitung dalam Angka. Pangkal Pinang: BPS-Statistics of Kepulauan Bangka Belitung Province (2019). p. 270-275. [in Bahasa Indonesia]. https://babel.bps.go.id/publication/2019/08/16/7f92e708e76a82369238a610/provinsikepulauan-bangka-belitung-dalam-angka-2019.html

10. H. Henri, L. Hakim, J. Batoro, Journal of Indonesian Tourism and Development Studies, 5,3:145-154(2017). https://jitode.ub.ac.id/index.php/jitode/article/view/228

11. N.K. Aliman, S.M. Hashim., S.D.M. Wahid, S. Harudin, International Journal of Marketing Studies, 8,3:174(2016).

https://www.researchgate.net/publication/303554285_Tourists'_Satisfaction_with_a Destination_An_Investigation_on_Visitors_to_Langkawi_Island

12. A.Said, A.Shuib, N.Ayob, F.Yaakub, International Journal of Business and Society, 14,1:62-63(2013).

http://www.ijbs.unimas.my/repository/pdf/AN\%20EVALUATION\%20OF\%20SERV ICE\%20QUALITY\%20pg61-78.pdf

13. M.N. Khuong, P.D. Luan, International Journal of Innovation, Management, and Technology, 6,4:238-239(2015). http://www.ijimt.org/vol6/609-BM00004.pdf

14. V.R. Efrida, I.N. Sudiarta, N.P.E. Mahadewi, Jurnal IPTA, 5,1:53-59(2017). [in Bahasa Indonesia]. https://ojs.unud.ac.id/index.php/pariwisata/article/view/29658/18281 
15. D. Bismantoro, A.A.H. Suryana, W. Pamungkas, A. Nurhayati, Jurnal Perikanan dan Kelautan, IX,2:87-89(2018). [in Bahasa Indonesia]. http://jurnal.unpad.ac.id/jpk/article/download/20521/9379

16. I. Nugroho, P.D. Negara, H.R. Yuniar, Journal of Socioeconomics and Development, 1,1:43-49(2018). https://media.neliti.com/media/publications/231649-the-planningand-the-development-of-the-3bf9a64f.pdf

17. I. Maulana, M.C. Aprianto, Jurnal Ekonomi dan Bisnis, 9,1:50-58(2018). [in Bahasa Indonesia]. https://stiemuttaqien.ac.id/ojs/index.php/OJS/article/download/60/54/

18. A. Budirachminarni, M.S.W. Suliswanto, Jurnal Ekonomi Pembangunan, 15,1:105116(2017). [in Bahasa Indonesia].

https://media.neliti.com/media/publications/162994-ID-analisis-kepuasanpengunjung-ekowisata-k.pdf

19. C.C. Miller, Challenges and Potentials of Ecotourism as a form of Conservation and Sustainable Development on Zepatera Island, Nicaragua. [Thesis], Enviromental Science (EnvEuro) Uppsala, Swedish (2017), p. 32-34. https://stud.epsilon.slu.se/10096/1/miller_c c c 170406.pdf

20. A. Idi, Cina-Melayu di Bangka, [Assimilation of Chinese and Malays in Bangka]. Yogyakarta: Tiara Wacana (2009. https://www.nlb.gov.sg/biblio/13369116

21. Elvian. Village in Bangka Volume I. Pangkal Pinang: Dinas Kebudayaan, Pariwisata, Pemuda, dan Olahraga Kota Pangkal Pinang (2014). p.7-9. [in Bahasa Indonesia]. [Online unpublished].

22. Purnama. History of Tin Mining and Chinese Ethnic Existence on Kelekak Sejarah Bangka, Department of culture and tourism of Bangka Regency. Sungailiat: Dinas Kebudayaan dan Pariwisata Kabupaten Bangka (2015). p. 206; 204. [in Bahasa Indonesia]. [Online unpublished].

23. M.S. Sapari, A. Shuib, S. Ramachandran, S.H.M. Afandi, Journal of Applied Economics and Business, 1,4:25-42(2013). http://www.aebjournal.org/articles/0104/010403.pdf

24. E. Rosman. Presentation Paper of Governor of Bangka Belitung in Coordination Meeting in 2018 at Nusa Dua, Bali, 13 March 2018 (2018). [in Bahasa Indonesia]. [Online unpublished].

25. Local Regulation No. 14/ 2017 Bangka Belitung Islands Provincial Medium-Term Development Plan for 2017-2022 (2017). [in Bahasa Indonesia]. [Online unpublished].

26. A.M. Lestari, M. Multifiah, A. Hoetoro, Journal of Indonesian Tourism and Development Studies, 6,1:23-32(2018). http://jitode.ub.ac.id/index.php/jitode/article/view/238

27. D. Fennell, Ecotourism, London \& New York: Routledge Taylor \& Francais Group (2008). p. 2. https://www.routledge.com/Ecotourism-4thEdition/Fennell/p/book/9780415829656

28. S. Suddin, Journal of Indonesian Tourism and Development Studies, 5,2:107112(2017). http://jitode.ub.ac.id/index.php/jitode/article/view/220 